\title{
Analysis of the Combination of Periodic Water Injection and Drilling off in Zone A
}

\author{
Shengrui Lou \\ The 3rd Oil Production Factory, Daqing Oil Field Company Ltd, Daqing, China
}

\begin{abstract}
In recent years, the number of new wells has been increasing continuously, which has a large impact on production. During the drilling pass, the formation pressure has dropped greatly, the casing loss rate is high, and the water cut has increased, which affects the overall development situation of Zone A. In this paper, by studying the rule of index change in the process of drilling off and periodic water injection, the technology of combining drilling off and periodic water injection has been formed, and the application of the drilling off in Zone A has been completed.
\end{abstract}

\section{Mechanism and method of periodic water injection}

Periodic water injection[1.2] is to periodically change the injection volume and production volume, causing unstable pressure field in the oil layer, so that the fluid is continuously redistributed and exchanged between the layers in the formation, thereby promoting the capillary imbibition of water and increasing the water injection sweep coefficient and oil washing efficiency. They all can improve the ultimate oil recovery.

Layer stop and well stop are the most important methods of periodic water injection. Layer stop is to select some of the intervals of the water injection well to implement periodic water injection, while well stop is to stop the injection of the entire well on a periodic basis. Layer stop mainly solves the vertical contradictions[3.4]. Well stop is to relieve the contradiction on the plane. In practical applications, the two methods are generally combined to implement.

The mechanical mechanism is to periodically control or stop the injection by water injection wells, which produces incidental pressure difference between the intervals of different permeability sedimentary units in the vertical heterogeneous oil layer, leading to additional channeling. This additional channeling can play a role in the comprehensive water cut of the homogeneous oil layer stratified section, and at the same time can reduce the comprehensive water cut rising speed and improve the development mode. Moreover, under the condition of conventional water injection, the greater the difference in permeability between the intervals, the more prominent the contradiction, and the more obvious the effect of periodic water injection. As the difference in permeability and saturation increases, the additional pressure difference between the intervals increases. Therefore, in one cycle of periodic water injection, the more water seeps and flows from the good layer to the poor layer, and the more oil flows in the opposite direction. This is reflected in the index that the rate of increase of water cut slows down or even water cut drops. It reduces inefficient and ineffective cycles and improves development results.

\section{Analysis of drilling off rules}

Drilling off is to shut in the original oil and water wells to relieve pressure and stabilize the pressure when new wells are drilled in the mined blocks to ensure drilling safety and cementing quality. There is no research and application of the combination of periodic water injection and drilling off.

In order to more accurately predict the impact of drilling off on production in the preparation of crude oil annual planning, this paper adopts multiple linear regression theory to determine the factors that affect production before drilling off, such as well pattern density, water cut, flow coefficient, oil production intensity, oil The ratio of the number of wells, water injection intensity and formation pressure were analyzed by regression analysis. The regression method was adopted to screen the variables, and a relatively optimal prediction equation was established. It has been verified that the established regression equation has high prediction accuracy and can meet actual requirements.

Through the method of gray correlation[5] and mathematical matrix calculation method, and the numerical simulation study combined with pressure changes, and the pressure change corresponding to the oil production water cut curve, so we can calculate and deduce the drilling recovery time and speed of water injection wells in different strata in Zone A.

The time range for basic formation wells to basically recover to $95 \%$ of the oil production level before shut-in under different pressure conditions is $18 \mathrm{~d}-72 \mathrm{~d}$, and the average recovery speed range is $0.1000 \% / \mathrm{d}-0.3751 \% / \mathrm{d}$.

\footnotetext{
a Corresponding author: loushengrui@petrochina.com.cn
} 
The time range for an infill well to basically recover to $95 \%$ of the oil production level before shut-in under different pressure conditions is $9 \mathrm{~d}-38 \mathrm{~d}$, and the average recovery speed range is $0.2561 \% / \mathrm{d}-0.3883 \% / \mathrm{d}$. It takes 35 days for the secondary infill well to basically recover to $95 \%$ of the oil production level before shut-in under different pressure conditions, and the average recovery speed range is $0.0031 \% / \mathrm{d}-0.1720 \% / \mathrm{d}$. It takes 35 days for the third infill well to basically recover to $95 \%$ of the oil production level before shut-in under different pressure conditions, and the average recovery speed range is $0.0031 \% / \mathrm{d}-0.1720 \% / \mathrm{d}$.

\section{Drilling off combined with periodic water injection}

Based on the conceptual model of the formation pressure distribution of the adjustment well in the drill-off area established by the periodic water injection institute, a calculation software for the formation pressure distribution of the adjustment well in the drill-off area for the splitting and transfer of small layers of liquid was compiled. Combining the actual dynamic and static parameters of the drilling area in Zone A, the pressure distribution around the water injection well, the pressure distribution around the oil production well, and the pressure distribution between the oil wells and water wells can be calculated. Based on the above conditions, the plane pressure distribution field can be calculated and we can analysis the drill off rule in Zone A.

Table 1. Principles for the recovery of drilling off in each layer

\begin{tabular}{|c|c|c|c|c|c|c|c|}
\hline \multirow{2}{*}{$\begin{array}{c}\text { Well } \\
\text { pattern }\end{array}$} & \multirow{2}{*}{$\begin{array}{l}\text { Main fluid } \\
\text { producing } \\
\text { reservoir }\end{array}$} & \multirow{2}{*}{$\begin{array}{c}\text { Average } \\
\text { formation } \\
\text { pressure } \\
/ \mathrm{MPa}\end{array}$} & \multirow{2}{*}{$\begin{array}{c}\text { Water } \\
\text { content } \\
\text { level } / \%\end{array}$} & \multirow{2}{*}{$\begin{array}{l}\text { Difference } \\
\text { s between } \\
\text { layers }\end{array}$} & \multicolumn{2}{|c|}{ Principles for the recovery of drilling off } & \multirow[t]{2}{*}{ purpose } \\
\hline & & & & & Side of water wells & Side of oil wells & \\
\hline $\begin{array}{c}\text { Basic well } \\
\text { pattern }\end{array}$ & $\begin{array}{l}\text { S main oil } \\
\text { reservoir }\end{array}$ & 11.35 & 96 & Smaller & $\begin{array}{l}\text { The recovery water } \\
\text { volume in the second stage } \\
\text { is determined according to } \\
\text { the oil layer conditions }\end{array}$ & $\begin{array}{c}\text { Adjust the } \\
\text { parameters } \\
\text { appropriately }\end{array}$ & $\begin{array}{c}\text { Restore formation } \\
\text { pressure, increase } \\
\text { production } \\
\text { thickness, control } \\
\text { liquid production } \\
\text { in high } \\
\text { water-bearing } \\
\text { layers }\end{array}$ \\
\hline $\begin{array}{l}\text { One-time } \\
\text { dense well } \\
\text { pattern }\end{array}$ & PII-GI9 & 11.95 & 95.44 & Bigger & $\begin{array}{c}\text { Sectional recovery and } \\
\text { water reduction } \\
\text { The recovery water } \\
\text { volume in the second stage } \\
\text { is determined according to } \\
\text { the oil layer conditions }\end{array}$ & $\begin{array}{l}\text { In theory, the } \\
\text { parameters can } \\
\text { be adjusted } \\
\text { appropriately }\end{array}$ & $\begin{array}{l}\text { Control the } \\
\text { pressure of the } \\
\text { high pressure } \\
\text { layer, increase the } \\
\text { thickness of } \\
\text { production, and } \\
\text { control the rise of } \\
\text { water content }\end{array}$ \\
\hline $\begin{array}{l}\text { Secondary } \\
\text { infill well } \\
\text { pattern }\end{array}$ & $\begin{array}{l}\text { Shin and } \\
\text { poor oil } \\
\text { reservoir }\end{array}$ & 10.24 & 95.63 & Big & $\begin{array}{c}\text { Direct recovery, water } \\
\text { lifting, subdivision, profile } \\
\text { control } \\
\text { The recovery water } \\
\text { volume is determined } \\
\text { according to the oil layer } \\
\text { conditions }\end{array}$ & $\begin{array}{c}\text { Adjust the } \\
\text { parameters } \\
\text { appropriately }\end{array}$ & $\begin{array}{l}\text { Restore formation } \\
\text { pressure, improve } \\
\text { the production of } \\
\text { low aquifers, and } \\
\text { control the rise of } \\
\text { water cut }\end{array}$ \\
\hline $\begin{array}{c}\text { Three } \\
\text { times } \\
\text { dense well } \\
\text { pattern }\end{array}$ & GI9-GII & 11.10 & 93.63 & Big & $\begin{array}{l}\text { Sectional recovery, } \\
\text { subdivision, profile control } \\
\text { The recovery water } \\
\text { volume in the second stage } \\
\text { is determined according to } \\
\text { the oil layer conditions }\end{array}$ & $\begin{array}{l}\text { In theory, the } \\
\text { parameters can } \\
\text { be adjusted } \\
\text { appropriately }\end{array}$ & $\begin{array}{c}\text { Restore formation } \\
\text { pressure, control } \\
\text { the rise of water } \\
\text { cut in new wells, } \\
\text { increase phased } \\
\text { oil production, } \\
\text { and increase the } \\
\text { degree of } \\
\text { production of low } \\
\text { aquifers }\end{array}$ \\
\hline
\end{tabular}

Table 2. Principles of water injection recovery in different well areas

\begin{tabular}{|l|c|c|c|}
\hline \multirow{2}{*}{ classification } & \multicolumn{2}{|c|}{ recovery steps of Drilling off } & \multirow{2}{*}{$\begin{array}{c}\text { The number of } \\
\text { execution wells }\end{array}$} \\
\cline { 2 - 3 } & $\begin{array}{c}\text { The first } \\
\text { step }\end{array}$ & The second step & \\
\hline Water dropping area of oil wells & $40 \%$ & $60-80 \%$ & 35 \\
\hline
\end{tabular}




\begin{tabular}{|c|c|c|c|}
\hline $\begin{array}{c}\text { If the water-bearing area of the oil well is rising, the } \\
\text { water-flooded data of the new well is interpreted as a } \\
\text { medium-low water-flooded zone, then it is necessary to } \\
\text { improve the low-aquifer }\end{array}$ & $60-80 \%$ & $100-120 \%$ & 12 \\
\hline $\begin{array}{c}\text { If the water content of the oil wells is stable, then the water } \\
\text { injection rate can be kept stable }\end{array}$ & $60 \%$ & $100 \%$ & 24 \\
\hline $\begin{array}{c}\text { If the formation pressure is low and the water content is low, } \\
\text { the water volume can be restored in one step }\end{array}$ & $100 \%$ & 13 \\
\hline $\begin{array}{c}\text { Underload well area, combination of water lifting and } \\
\text { controlled water injection, it can be carried out targeted } \\
\text { adjustment }\end{array}$ & $100 \%$ & 7 \\
\hline
\end{tabular}

\subsection{Shut-in boundary before drilling}

By analyzing the formation pressure distribution field of the block, determine the range of oil and water wells that determine the pressure situation at any position in the space, that is, the number of drilled wells and the drilled area. The specific method is to use the pressure calculation model to calculate the formation pressure in the steady state before determining the stop of the injection well to reduce the pressure. That is, the formation pressure before the shut-in of the water injection well, and then the injection stop calculation is performed on each injection well from near to far, so as to calculate the formation pressure at the point to be drilled after the stop of drilling and injection.

The total shut-in time for drilling shut-in must take into account the pre-drilling shut-in time limits of different well patterns, as well as the length of the shut-in time during drilling off. Through the method of numerical simulation calculation, it is concluded that the time of stopping injection all the water wells within the waiting point of the basic well pattern, primary well pattern, secondary well pattern, and tertiary well pattern are $6 \mathrm{~d}, 9 \mathrm{~d}, 14 \mathrm{~d}$ and $14 \mathrm{~d}$ respectively. This time range can not only meet the needs of drilling off operations, but also minimize the impact of drilling off on production.

\subsection{The recovery limits of different layers during the period of drilling off}

According to the change law of production during the drilling shut-in operation, the total shut-in time limit for drilling shut-in in different oil layers can be determined when the injection is directly stopped. So as to lay the foundation for the next step to determine the technical boundary of the combination of drilling and periodic water injection. The total shut-in time for drilling shut-in should take into account the pre-drilling shut-in time limits of different well patterns and the length of the shut-in time during drilling off. If the total shut-in time is too short, it may not meet the drilling shut-in requirements. If it is too long, it may have a large impact on the output, and it is not conducive to the subsequent drilling and recovery process. Based on the actual dynamic data analysis of production changes during the shut-in and recovery periods, the production change during the shut-in period should not exceed $15 \%$. Based on this, the total shut-in time limit when drilling shut-in is implemented in different oil layers during normal shut-in can be determined.

A conceptual model is established based on the dynamic and static parameters of the strata controlled by the well pattern of each strata. Apply numerical simulation to study the recovery limits of water injection wells in different layers. Currently, the "two-step method" is commonly used to carry out drilling and recovery work. Practice has proved that the use of two-step recovery can not only effectively shorten the recovery period, but also significantly simplify construction operations. Accordingly, we also consider the "two-step method" when designing the plan. The formation pressure and water cut are normal. Based on the above-mentioned drilling shut-off recovery principle, in order to determine a reasonable recovery method for water injection wells, a drilling shut-off recovery plan is designed. And carry out numerical simulation research, compare 16 sets of plans for each layer, compare and analyze the influence of different plans on production indicators such as output and water cut. According to the drill-off recovery limits of different well patterns, the following recovery principles are determined as table 1 .

The water injection wells of the basic strata can be recovered in stages. The first stage recovers $80 \%$ of the water injection for 20 days. The water injection wells of the infill chromatography can be recovered in stages. The first stage recovers $60 \%$ of the water injection for 15 days. The water injection wells of the secondary infill layer system can be injected directly by recovering water injection. The water injection wells of the three infill wells can be recovered in stages. The first stage recovers $80 \%$ of the water injection for 20 days.

\subsection{Restoration boundary between layers}

According to the water-flooded interpretation data of the new well, combined with the change in the water cut of the oil wells during the drilling-off period, the drilling off recovery plans for different intervals such as the water cut down position, the water cut rise position, the water cut stable position, the low pressure position and the underloaded well layer, etc., are implemented, as are shown in table 2 . 


\section{Results achieved}

4.1 By combining with periodic water injection rules and parameter research, the number of drilling off wells is reduced, and the number of drilling off days is shortened

Through the advantageous combination of shut-in drilling and periodic water injection, the shut-in time is effectively shortened. In the three years, the planned average shut-in time is 53.3 days, and the actual shut-in time is 31.7 days, which is 21.6 days less than planned and 39 days shorter than before optimization.

4.2 Combined with the parameter law of periodic water injection, the drop of formation pressure in the drill pass is slowed down, and the impact on production is reduced

Before the application of the results, the formation pressure in the drill-off area has dropped significantly, and the decrease in formation pressure has slowed down. The average pressure in the drill-off area has dropped by only about $0.02 \mathrm{MPa}$ in three years; through scientific drilling operations and drill-off recovery, the cumulative number of drill-off areas has been less than three years. Affect the oil production of $2.26 \times 104 t$, and at the same time, the new well will be put into production early and produce $1.77 \times 104 \mathrm{t}$ more oil. The well area combined with periodic water injection hardly affects production.

4.3 The drilling pass combined with periodic water injection research is more reasonable, so that the cementing quality rate is higher than planned, and the casing damage rate is lower than the level of the whole area

Through scientific drilling and construction management, the three-year cementing quality and quality rates were $93.5 \%, 80.8 \%$, and $80.5 \%$, respectively, which were $17.5,4.8$, and 4.5 percentage points higher than planned.

\section{Conclusion}

In summary, a technical method combining drilling shut-off operation and recovery with periodic water injection is formed, which effectively reduces the impact of drilling shut-off and has significant application effects. The research results can guide oilfield drilling off operations, and can effectively reduce the impact on production and casing protection during the drilling pass. The formed drilling pass optimization and periodic water injection combined supporting technology and management methods can be promoted and applied in other drilling pass blocks and even the entire oil field.

\section{References}

1. Zhang, J.C., Bo, S.Z., Zhang, Y.J., Ban, Y.H. Acta Petroleum. Research on Periodic Water Injection
Experiment and Oil Increase Mechanism., 10 (2): 0253-2697. (2003)

2. He, F., Li, T,. Special oil and gas reservoir, Research on Technology of Periodic Water Injection to Improve Water Drive Efficiency. 3(10): 1006-6535. (2004)

3. Zhou L W, Oil and gas field surface engineering. An effective way to optimize drilling methods. 8:35-37(2004).

4. Wen, G.F., Ren, B.S., Ni, T.L., Shi, M.Y., Shen, H.H., Xiao, Y.Q. Research on Periodic Water Injection with Numbercial Simulation Technology, 1(10): 1000-0747. (2000)

5. Zhang, S.L., Zhang, G.L. System Engineering, Comparison of Grey Relational Degree Calculation Methods and Analysis of Existing Problems. 14(13):45-49. (1996) 